\title{
BILANGAN DOMINASI INVERS PADA GRAF ULAR SEGITIGA, ULAR SEGITIGA GANDA, ULAR SEGIEMPAT, ULAR SEGIEMPAT GANDA DAN GRAF PEMBANGUNNYA
}

\author{
Anggun Fitria Febrianti, Mariatul Kiftiah, Fransiskus Fran
}

\begin{abstract}
INTISARI
Pada suatu graf $G=(V, E)$, himpunan bagian $D$ dari $V(G)$ merupakan himpunan dominasi jika simpulsimpul yang tidak berada di $D$ bertetangga sedikitnya dengan satu simpul di $D$. Kardinalitas minimum dari $D$ disebut bilangan dominasi $(\gamma(G))$. Terdapat beberapa topik mengenai bilangan dominasi diantaranya bilangan dominasi invers. Misalkan $D$ merupakan himpunan dominasi dari graf $G$ dengan kardinalitas minimum. Suatu himpunan $D^{\prime}$ adalah himpunan dominasi invers jika $V-D$ memuat suatu himpunan dominasi yang terkait dengan $D$. Kardinalitas minimum dalam himpunan dominasi invers didefinisikan sebagai bilangan dominasi invers dari graf $G$ yang dinotasikan dengan $\gamma^{-1}(G)$. Penelitian ini mengkaji tentang bilangan dominasi invers pada beberapa graf yaitu graf lintasan $P_{n}$ dan graf cycle $C_{n}$ dengan $n$ simpul. Graf ular segitiga $S\left(T_{n}\right)$, graf ular segitiga ganda $D\left(T_{n}\right)$, graf ular segiempat $S\left(Q_{n}\right)$ dan graf ular segiempat ganda $D\left(Q_{n}\right)$ yang dibangun oleh graf lintasan dan cycle dengan $n \geq 3$ simpul. Berdasarkan penelitian diperoleh bahwa bilangan dominasi invers yaitu $\gamma^{-1}\left(P_{n}\right)=\left[\frac{n}{3}\right]+1$ untuk $n=3 k$ dengan $k \in \mathbb{N}$, $\gamma^{-1}\left(P_{n}\right)=\left\lceil\frac{n}{3}\right\rceil$ untuk n lainnya, $\gamma^{-1}\left(C_{n}\right)=\left\lceil\frac{n}{3}\right\rceil, \gamma^{-1}\left(S\left(T_{n}\right)\right)=\left\lceil\frac{n}{2}\right\rceil, \gamma^{-1}\left(D\left(T_{n}\right)\right)=\left\lceil\frac{n}{2}\right\rceil, \gamma^{-1}\left(S\left(Q_{n}\right)\right)=n$ dan $\gamma^{-1}\left(D\left(Q_{n}\right)\right)=2 n-2$.
\end{abstract}

Kata kunci : bilangan dominasi invers, graf lintasan, graf cycle, graf ular

\section{PENDAHULUAN}

Menurut catatan sejarah, graf merupakan teori yang diperkenalkan oleh Leonhard Euler pada tahun 1736 untuk menyelesaikan permasalahan jembatan Königsberg. Permasalahan jembatan Königsberg adalah mungkin tidaknya melalui ketujuh jembatan yang berada di kota Königsberg masing-masing tepat satu kali dan kembali lagi ke tempat semula. Euler memodelkan masalah ini ke dalam graf [1]. Teori graf memiliki beberapa jenis, salah satu jenis graf yang digunakan dalam penelitian ini adalah graf ular. Graf ular merupakan graf yang disusun dengan aturan penyusunan pada bidang menggunakan segitiga, dengan masing-masing segitiga bersisian pada paling sedikit satu sisi dengan lainnya. Graf ular dengan panjang $n \geq 3$ simpul adalah $n$-triomino dengan menempatkan $n$ segitiga [2]. Ada empat jenis graf ular yang digunakan dalam penelitian ini, diantaranya graf ular segitiga yang mengganti setiap sisi lintasan dengan $C_{3}$, graf ular segiempat yang mengganti setiap sisi lintasan dengan $C_{4}$, graf ular segitiga ganda yang memiliki dua segitiga yang sama dan graf ular segiempat ganda yang memiliki dua segiempat yang sama. Ada beberapa konsep dalam pembahasan teori graf, salah satunya adalah himpunan dominasi.

Himpunan dominasi adalah suatu himpunan bagian $D$ dari himpunan simpul $V(G)$ dengan simpulsimpul yang tidak berada di $D$ bertetangga sedikitnya dengan satu simpul di $D$. Kardinalitas minimum dari $D$ disebut bilangan dominasi $\gamma(G)$ [3]. Sejarah himpunan dominasi dimulai ketika penggemar catur Eropa mempelajari masalah "dominasi ratu". Dalam masalah ini, dominasi digunakan untuk menentukan banyaknya ratu sehingga setiap ratu bisa mendominasi atau menyerang setiap posisi dengan sekali perpindahan pada papan catur ukuran $8 \times 8$ [4]. Terdapat beberapa topik mengenai bilangan dominasi diantaranya yaitu bilangan dominasi invers. Misalkan $D$ merupakan himpunan 
dominasi dari graf $G$ dengan kardinalitas minimum. Suatu himpunan $D^{\prime}$ adalah himpunan dominasi invers jika $V-D$ memuat suatu himpunan dominasi yang terkait dengan $D$. Kardinalitas minimum dari himpunan dominasi invers didefinisikan sebagai bilangan dominasi invers dari graf $G$ yang dinotasikan dengan $\gamma^{-1}(G)$ [5].

Ore melakukan penelitian yang membahas tentang himpunan dominasi dalam jaringan [5]. Pada jaringan atau graf apapun himpunan dominasi adalah himpunan pusat dan memainkan peran penting dalam masalah pengiriman informasi pada komputasi paralel. Dalam menemukan himpunan dominasi yang efisien harus selalu memperhatikan pengoptimalan himpunan pusat dalam jaringan tersebut. Misalkan $S$ adalah himpunan dominasi dalam jaringan atau graf di $G$. Ketika jaringan gagal di beberapa komputer server dalam $S$, maka himpunan dominasi invers yaitu $V-S$ yang akan menggantikan peran $S$. Penelitian ini mengarah untuk mendefinisikan bilangan dominasi invers [6].

Pada penelitian [7] telah dibahas bilangan dominasi pada graf ular segitiga, graf ular segitiga ganda, graf ular segiempat, dan graf ular segiempat ganda. Pada penelitian ini, mengembangkan penelitian sebelumnya dengan mencari formula bilangan dominasi invers pada graf ular segitiga, graf ular segitiga ganda, graf ular segiempat, dan graf ular segiempat ganda.

\section{GRAF ULAR}

Graf $G$ didefinisikan sebagai pasangan himpunan $(V, E)$, ditulis dengan notasi $G=(V, E)$, yang dalam hal ini $V$ adalah himpunan tidak-kosong dari simpul-simpul (vertices) dan $E$ adalah himpunan sisi (edges) yang menghubungkan sepasang simpul. Sebuah graf dimungkinkan tidak mempunyai sisi satu buah pun, tetapi simpulnya harus ada, minimal satu [1]. Dalam penelitian ini simpul pada graf dinyatakan dengan $u_{i}$ atau $v_{i}$ untuk $i \in \mathbb{N}$.

Beberapa terminologi dasar yang berkaitan dengan teori graf yang digunakan dalam penelitian ini yaitu bertetangga (adjacent), lintasan (path) dan lingkaran (cycle) [1]. Dua buah simpul pada graf takberarah $G$ dikatakan bertetangga bila keduanya terhubung langsung dengan sebuah sisi. Dengan kata lain, $u$ bertetangga dengan $v$ jika $(u, v)$ adalah sebuah sisi pada graf $G$. Lintasan yang panjangnya $n$ dari simpul awal $v_{1}$ ke simpul tujuan $v_{n}$ di dalam graf $G$ ialah barisan berselang-seling simpul-simpul dan sisi-sisi yang berbentuk $v_{1}, e_{1}, v_{2}, e_{2}, \ldots, v_{n-1}, e_{n}, v_{n}$ sedemikian sehingga $e_{1}=\left(v_{1}, v_{2}\right), e_{2}=$ $\left(v_{2}, v_{3}\right), \ldots, e_{n}=\left(v_{n-1}, v_{n}\right)$ adalah sisi-sisi dari graf $G$. Lintasan yang berawal dan berakhir pada simpul sama disebut sirkuit atau siklus (cycle). Graf dapat dikelompokkan menjadi beberapa jenis, dalam penelitian ini jenis graf yang digunakan adalah graf ular. Berikut definisi terkait graf ular.

Definisi 1 [2] Graf ular dengan panjang $T_{n}$ adalah n-triomino, dengan menempatkan $n$ segitiga sama sisi.

Bentuk graf ular dapat dilihat pada Gambar 1.

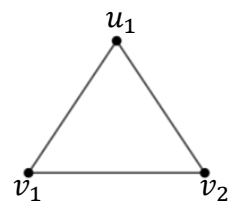

(a)

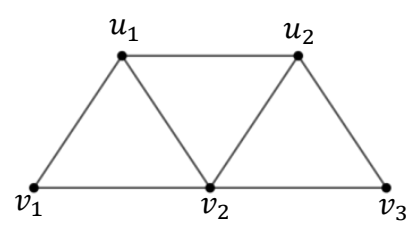

(b)

\section{Gambar 1 (a) Graf Ular $T_{3}$, (b) Graf Ular $T_{5}$}

Ada beberapa jenis graf ular yang digunakan dalam penelitian ini diantaranya adalah graf ular segitiga, graf ular segitiga ganda, graf ular segiempat dan graf ular segi empat ganda. Berikut definisi terkait graf tersebut. 


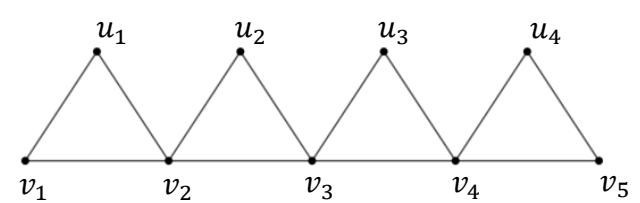

(a)

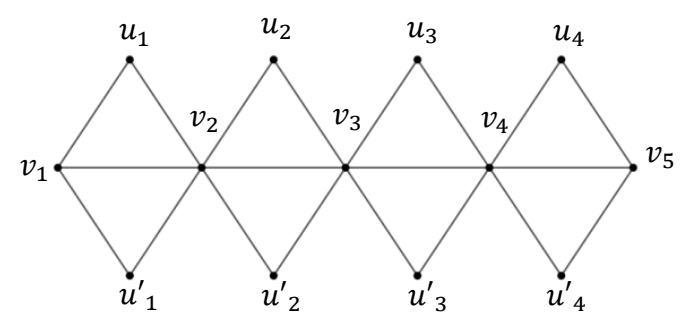

(c)

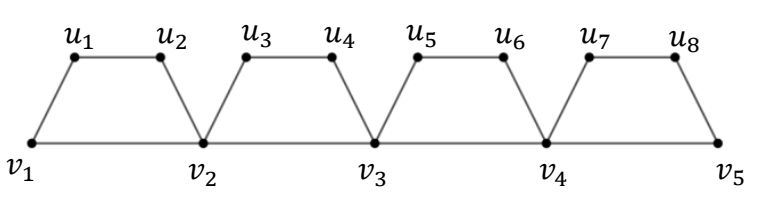

(b)

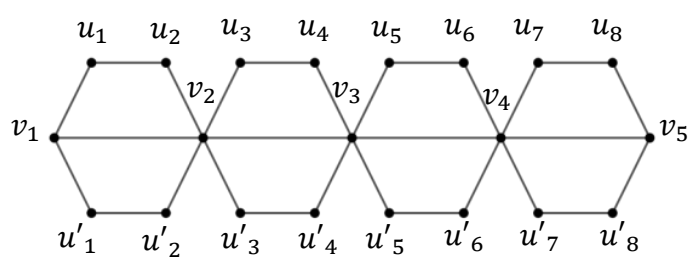

(d)

Gambar 2 Graf Ular dengan 4 Jenis

Pada Gambar 2 (a) merupakan graf ular segitiga (triangular snake graph) $S\left(T_{n}\right.$ ) yaitu graf yang dibentuk dari lintasan yang mengganti setiap sisi lintasan dengan segitiga $C_{3}$ [7]. Pada Gambar 2 (b) merupakan graf ular segiempat (quadrilateral snake graph) $S\left(Q_{n}\right)$ yaitu graf yang dibentuk dari lintasan yang mengganti setiap sisi lintasan dengan segiempat $C_{4}$ [7]. Pada Gambar 2 (c) merupakan graf ular segitiga ganda (double triangular snake graph) $D\left(T_{n}\right)$ yaitu terdiri dari dua segitiga yang memiliki lintasan yang sama [7]. Pada Gambar 2 (d) merupakan graf ular segiempat ganda (double quadrilateral snake graph) $D\left(Q_{n}\right)$ yaitu terdiri dari dua segiempat yang memiliki lintasan yang sama [7].

\section{BILANGAN DOMINASI}

Secara historis, masalah dominasi mulai dipelajari dari tahun 1950 oleh Hedetniemi dan Laskar, tetapi tingkat pengkajian meningkat secara signifikan pada pertengahan tahun 1970-an [3].

Definisi 2 [3] Diketahui graf $G=(V, E)$. Misalkan $D \subseteq V$. Jika setiap simpul dari $V-D$ saling bertetangga sedikitnya dengan satu simpul dari $D$, maka $D$ dikatakan himpunan dominasi pada graf $G$. Bilangan dominasi (domination number) yang dinotasikan dengan $\gamma(G)$ adalah kardinalitas minimum dari sebuah himpunan dominasi.

Contoh 3 Misal diberikan graf $G$ seperti pada Gambar 3 dengan 8 simpul dan 8 sisi. Selanjutnya, menentukan bilangan dominasi pada graf $G$ tersebut.

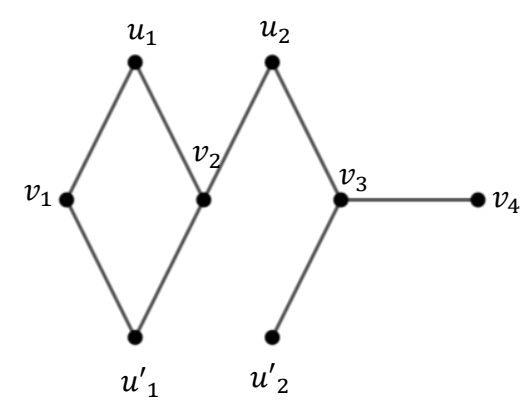

\section{Gambar 3 Bilangan Dominasi pada Graf G}

Pada Gambar 3 dapat dipilih beberapa kemungkinan himpunan dominasi pada graf $G$ yaitu $\left\{v_{1}, u_{2}, v_{3}\right\},\left\{v_{1}, v_{2}, v_{3}\right\}$ dan $\left\{v_{1}, v_{2}, u_{2}, v_{3}\right\}$. Berdasarkan tiga kemungkinan tersebut, didapat bilangan dominasi pada graf $G$ yaitu 3 . 
Adapun beberapa bilangan dominasi dari beberapa graf lainnya, yaitu graf lintasan $\gamma\left(P_{n}\right)=\left\lceil\frac{n}{3}\right\rceil[5]$, graf cycle $\gamma\left(C_{n}\right)=\left\lceil\frac{n}{3}\right\rceil$ [5], graf ular segitiga $\gamma\left(S\left(T_{n}\right)\right)=\left\lceil\frac{n-1}{2}\right\rceil$ [7], graf ular segitiga ganda $\gamma\left(D\left(T_{n}\right)\right)=\left\lceil\frac{n-1}{2}\right\rceil$ [7], graf ular segiempat $\gamma\left(S\left(Q_{n}\right)\right)=n$ dan graf ular segiempat ganda $\gamma\left(D\left(Q_{n}\right)\right)=n[7]$.

\section{BILANGAN DOMINASI INVERS}

Salah satu pengembangan dari bilangan dominasi yaitu bilangan dominasi invers.

Definisi 4 [3] Misalkan D merupakan himpunan dominasi dalam graf $G$ dengan kardinalitas minimum. Suatu himpunan $D^{\prime}$ adalah himpunan dominasi invers jika $V-D$ memuat suatu himpunan dominasi yang terkait dengan D. Kardinalitas minimum dari himpunan dominasi invers didefinisikan sebagai bilangan dominasi invers dari graf $G$ yang dinotasikan dengan $\gamma^{-1}(G)$. Berdasarkan definisi bilangan dominasi invers $\gamma(G) \leq \gamma^{-1}(G)$.

\section{Bilangan Dominasi Invers pada $\boldsymbol{P}_{\boldsymbol{n}}$}

Berikut ini diberikan proposisi untuk graf lintasan $P_{n}$ :

Proposisi 5 [3] Diberikan graf lintasan $P_{n}$ dengan $n$ simpul, maka bilangan dominasi invers $\gamma^{-1}\left(P_{n}\right)=\left\{\begin{array}{c}\left\lceil\frac{n}{3}\right\rceil+1, n=3 k \\ \left\lceil\frac{n}{3}\right\rceil, n \text { lainnya }\end{array}\right.$

Contoh 6 Diberikan graf lintasan $\mathrm{P}_{3}$.

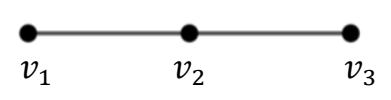

\section{Gambar 4 Graf $P_{3}$}

Pada Gambar 4 dapat dilihat himpunan dominasi pada graf $\mathrm{P}_{3}$ dengan kardinalitas minimum yaitu $D=\left\{v_{2}\right\}$ dengan simpul $v_{2}$ mendominasi simpul $\left\{v_{1}, v_{3}\right\}$. Himpunan $V-D$ adalah $\left\{v_{1}, v_{3}\right\}$ saling bertetangga dengan simpul dari $D$. Simpul $v_{1}$ mendominasi simpul $\left\{v_{2}\right\}$ dan simpul $v_{3}$ mendominasi simpul $\left\{v_{2}\right\}$. Akibatnya himpunan dominasi invers dengan kardinalitas minimum adalah $D^{\prime}=\left\{v_{1}, v_{3}\right\}$ dan diperoleh bilangan dominasi invers $\gamma^{-1}\left(\mathrm{P}_{3}\right)=2$.

\section{Bilangan Dominasi Invers pada $\boldsymbol{C}_{\boldsymbol{n}}$}

Berikut ini diberikan proposisi untuk graf cycle $C_{n}$ :

Proposisi 7 [3] Diberikan graf cycle $C_{n}$ dengan n simpul, maka bilangan dominasi invers $\gamma^{-1}\left(C_{n}\right)=$ $\left\lceil\frac{n}{3}\right\rceil$.

Contoh 8 Diberikan graf cycle $\mathrm{C}_{3}$.

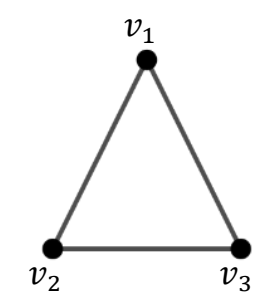

Gambar 5 Graf $C_{3}$ 
Pada Gambar 5 dapat dilihat himpunan dominasi pada graf $\mathrm{C}_{3}$ dengan kardinalitas minimum yaitu $D=\left\{v_{2}\right\}$ dengan simpul $v_{2}$ mendominasi simpul $\left\{v_{1}, v_{3}\right\}$. Himpunan $V-D$ adalah $\left\{v_{1}, v_{3}\right\}$ saling bertetangga dengan simpul dari $D$. Simpul $v_{1}$ mendominasi simpul $\left\{v_{2}, v_{3}\right\}$. Akibatnya himpunan dominasi invers dengan kardinalitas minimum adalah $D^{\prime}=\left\{v_{1}\right\}$ dan diperoleh bilangan dominasi invers $\gamma^{-1}\left(\mathrm{C}_{3}\right)=1$.

\section{Bilangan Dominasi Invers pada $S\left(T_{n}\right)$}

Berikut ini diberikan proposisi untuk graf ular segitiga $S\left(T_{n}\right)$ :

Proposisi 9 Diberikan graf ular segitiga $S\left(T_{n}\right)$ dengan $n \geq 3$, maka bilangan dominasi invers $\gamma^{-1}\left(S\left(\mathrm{~T}_{n}\right)\right)=\left\lceil\frac{n}{2}\right\rceil$.

Bukti : Diberikan graf ular segitiga dengan $n \geq 3$ dan himpunan simpul $V\left(\mathrm{~S}\left(\mathrm{~T}_{n}\right)\right)=\left\{v_{1}, v_{2}\right.$, $\left.\ldots, v_{n}, u_{1}, u_{2}, \ldots, u_{2 n-2}\right\}$. Ambil $v_{i} \in V\left(\mathrm{~S}\left(\mathrm{~T}_{n}\right)\right)$ dengan $i \in\{2, \ldots, n-1\}$ sehingga $v_{i}$ mendominasi simpul pada $\left\{v_{i-1}, v_{i+1}, u_{i-1}, u_{i}\right\}$. Karena berdasarkan Definisi $2, v_{i}$ bertetangga dengan simpul pada $\left\{v_{i-1}, v_{i+1}, u_{i-1}, u_{i}\right\}$. Akibatnya, setiap simpul bisa mendominasi maksimal 4 simpul disekitarnya untuk $i$ lainnya hanya bisa mendominasi maksimal 2 simpul disekitarnya, sehingga diperoleh himpunan dominasi untuk graf ular segitiga salah satunya yaitu

1. $D=\left\{v_{2}, v_{4}, v_{6}, \ldots, v_{n}\right\}$ untuk $n$ genap

2. $D=\left\{v_{2}, v_{4}, \ldots, v_{n-1}\right\}$ untuk $n$ ganjil

Selanjutnya ambil $v_{j} \in V-D$ dengan $j \in\{1, \ldots, n\}$ sehingga $v_{j}$ mendominasi $\left\{u_{j-1}, u_{j}, v_{j-1}, v_{j+1}\right\}$. Oleh karena itu dapat dipilih salah satu himpunan dominasi invers pada graf $\mathrm{S}\left(\mathrm{T}_{n}\right)$ yaitu $D^{\prime}=$ $\left\{v_{1}, v_{3}, v_{5}, \ldots, v_{2}\left(\left[\frac{n}{2}\right]\right)-1\right\}$. Bilangan dominasi invers dihitung dari banyaknya anggota pada himpunan $D^{\prime}$. Berdasarkan indeks pada himpunan $D^{\prime}$, simpul pertamanya dimulai dari $v_{1}$ dan beda 2 untuk simpul selanjutnya. Pada himpunan $D^{\prime}$ indeks terbesarnya adalah $2\left(\left\lceil\frac{n}{2}\right\rceil\right)-1$. Indeks pada himpunan $D^{\prime}$ dapat disusun menjadi suatu barisan aritmatika sebagai berikut :

$$
D^{\prime}=\left\{1,3,5, \ldots, 2\left(\left\lceil\frac{n}{2}\right\rceil\right)-1\right\}
$$

Banyaknya anggota himpunan tersebut dapat diperoleh dengan menggunakan rumus barisan aritmatika dengan beda 2 dan suku pertama 1 sehingga pada himpunan $D^{\prime}$ suku ke $n$ yaitu $\left\lceil\frac{n}{2}\right]$. Akibatnya, banyaknya anggota himpunan dominasi invers yang paling sedikit dari graf ular segitiga haruslah $\gamma^{-1}\left(\mathrm{~S}\left(\mathrm{~T}_{n}\right)\right) \leq\left\lceil\frac{n}{2}\right\rceil$. Selanjutnya akan ditunjukkan bilangan dominasi invers pada graf ular segitiga adalah $\gamma^{-1}\left(\mathrm{~S}\left(\mathrm{~T}_{n}\right)\right)=\left\lceil\frac{n}{2}\right\rceil$. Misal $\gamma^{-1}\left(\mathrm{~S}\left(\mathrm{~T}_{n}\right)\right)=\left\lceil\frac{n}{2}\right\rceil-1$, maka terdapat $\left\lceil\frac{n}{2}\right\rceil-1$ simpul yang merupakan himpunan dominasi invers pada graf ular segitiga dengan kardinalitas minimum. Jika terdapat $\left\lceil\frac{n}{2}\right\rceil-1$ simpul pada himpunan dominasi invers yang dipilih sembarang, bisa dipilih pada simpul yang mendominasi paling minimum yaitu 2 simpul sampai yang paling maksimum yaitu 4 simpul. Akibatnya terdapat minimal satu simpul pada graf $\mathrm{S}\left(\mathrm{T}_{n}\right)$ yang tidak terdominasi. Untuk $n$ ganjil maka terdapat satu simpul tidak terdominasi, untuk $n$ genap maka terdapat 3 simpul tidak terdominasi. Hal tersebut kontradiksi dengan definisi bilangan dominasi invers, dengan kata lain haruslah $\gamma^{-1}\left(\mathrm{~S}\left(\mathrm{~T}_{n}\right)\right)=\left\lceil\frac{n}{2}\right\rceil$. Jadi, dapat disimpulkan bilangan dominasi invers pada graf ular segitiga yaitu $\gamma^{-1}\left(\mathrm{~S}\left(\mathrm{~T}_{n}\right)\right)=\left\lceil\frac{n}{2}\right\rceil$.

Contoh 10 Diberikan graf ular segitiga $S\left(T_{3}\right)$. 


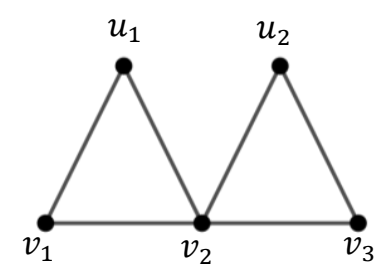

Gambar 6 Graf $S\left(T_{3}\right)$

Pada Gambar 6 dapat dilihat himpunan dominasi pada graf $S\left(T_{3}\right)$ dengan kardinalitas minimum yaitu $D=\left\{v_{2}\right\}$ dengan simpul $v_{2}$ mendominasi simpul $\left\{v_{1}, u_{1}, u_{2}, v_{3}\right\}$. Himpunan $V-D$ adalah $\left\{v_{1}, u_{1}, u_{2}, v_{3}\right\}$ saling bertetangga dengan simpul dari $D$. Simpul $v_{1}$ mendominasi simpul $\left\{u_{1}, v_{2}\right\}$ dan simpul $v_{3}$ mendominasi simpul $\left\{v_{2}, u_{2}\right\}$. Akibatnya himpunan dominasi invers dengan kardinalitas minimum adalah $D^{\prime}=\left\{v_{1}, v_{3}\right\}$ dan diperoleh bilangan dominasi invers $\gamma^{-1} \mathrm{~S}\left(\mathrm{~T}_{3}\right)=2$.

\section{BILANGAN DOMINASI INVERS PADA GRAF $D\left(T_{n}\right)$}

Berikut ini diberikan proposisi untuk graf ular segitiga ganda $D\left(T_{n}\right)$ :

Proposisi 11 Diberikan graf ular segitiga ganda $D\left(T_{n}\right)$ dengan $n \geq 3$, maka bilangan dominasi invers $\gamma^{-1}\left(\mathrm{D}\left(\mathrm{T}_{n}\right)\right)=\left\lceil\frac{n}{2}\right\rceil$.

Bukti : Diberikan graf ular segitiga ganda dengan $n \geq 3$ dan himpunan simpul $V\left(\mathrm{D}\left(\mathrm{T}_{n}\right)\right)=$ $\left\{v_{1}, v_{2}, \ldots, v_{n}, u_{1}, u_{2}, \ldots, u_{2 n-2}, u_{1}^{\prime}, u_{2}^{\prime}, \ldots, u_{2 n-2}^{\prime}\right\}$. Ambil $v_{i} \in V\left(\mathrm{D}\left(\mathrm{T}_{n}\right)\right)$ dengan $i \in\{2, \ldots, n-1\}$ sehingga $v_{i}$ mendominasi simpul pada $\left\{v_{i-1}, v_{i+1}, u_{i-1}, u_{i}, u_{i-1}^{\prime}, u_{i}^{\prime}\right\}$. Karena berdasarkan Definisi 2 $v_{i}$ bertetangga dengan simpul pada $\left\{v_{i-1}, v_{i+1}, u_{i-1}, u_{i}, u_{i-1}^{\prime}, u_{i}^{\prime}\right\}$. Akibatnya, setiap simpul bisa mendominasi maksimal 6 simpul disekitarnya untuk $i$ lainnya hanya bisa mendominasi maksimal 3 simpul disekitarnya, sehingga diperoleh himpunan dominasi untuk graf ular segitiga ganda salah satunya yaitu

1. $D=\left\{v_{2}, v_{4}, v_{6}, \ldots, v_{n}\right\}$ untuk $n$ genap

2. $D=\left\{v_{2}, v_{4}, \ldots, v_{n-1}\right\}$ untuk $n$ ganjil

Selanjutnya ambil $v_{j} \in V-D$ dengan $j \in\{1, \ldots, n\}$ sehingga $v_{j}$ mendominasi simpul pada $\left\{u_{j-1}\right.$, $\left.u_{j}, v_{j-1}, v_{j+1}, u_{j-1}^{\prime}, u_{j}^{\prime}\right\}$. Oleh karena itu dapat dipilih salah satu himpunan dominasi invers pada graf $\mathrm{D}\left(\mathrm{T}_{n}\right)$ yaitu $D^{\prime}=\left\{v_{1}, v_{3}, v_{5}, \ldots, v_{2\left(\left[\frac{n}{2}\right]\right)-1}\right\}$. Bilangan dominasi invers dihitung dari banyaknya anggota pada himpunan $D^{\prime}$. Berdasarkan indeks pada himpunan $D^{\prime}$, simpul pertamanya dimulai dari $v_{1}$ dan beda 2 untuk simpul selanjutnya. Pada himpunan $D^{\prime}$ indeks terbesarnya adalah $2\left(\left[\frac{n}{2}\right\rceil\right)-1$. Indeks pada himpunan $D^{\prime}$ dapat disusun menjadi suatu barisan aritmatika sebagai berikut :

$$
D^{\prime}=\left\{1,3,5, \ldots, 2\left(\left\lceil\frac{n}{2}\right\rceil\right)-1\right\}
$$

Banyaknya anggota himpunan tersebut dapat diperoleh dengan menggunakan rumus barisan aritmatika dengan beda 2 dan suku pertama 1 sehingga pada himpunan $D^{\prime}$ suku ke $n$ yaitu $\left\lceil\frac{n}{2}\right\rceil$. Akibatnya, banyaknya anggota himpunan dominasi invers yang paling sedikit dari graf ular segitiga ganda haruslah $\gamma^{-1}\left(\mathrm{D}\left(\mathrm{T}_{n}\right)\right) \leq\left[\frac{n}{2}\right]$. Selanjutnya akan ditunjukkan bilangan dominasi invers pada graf ular segitiga ganda adalah $\gamma^{-1}\left(\mathrm{D}\left(\mathrm{T}_{n}\right)\right)=\left\lceil\frac{n}{2}\right\rceil$. Misal $\gamma^{-1}\left(\mathrm{D}\left(\mathrm{T}_{n}\right)\right)=\left\lceil\frac{n}{2}\right\rceil-1$, maka terdapat $\left\lceil\frac{n}{2}\right\rceil-1$ simpul yang merupakan himpunan dominasi invers pada graf ular segitiga ganda dengan kardinalitas minimum. Jika terdapat $\left\lceil\frac{n}{2}\right\rceil-1$ simpul pada himpunan dominasi invers yang dipilih sembarang, bisa dipilih pada simpul yang mendominasi paling minimum yaitu 3 simpul sampai yang paling maksimum yaitu 6 simpul. Akibatnya terdapat minimal 2 simpul pada graf $\mathrm{D}\left(\mathrm{T}_{n}\right)$ yang tidak terdominasi. Untuk $n$ 
ganjil maka terdapat 2 simpul tidak terdominasi, untuk $n$ genap maka terdapat 5 simpul tidak terdominasi. Hal tersebut kontradiksi dengan definisi bilangan dominasi invers, dengan kata lain haruslah $\gamma^{-1}\left(\mathrm{D}\left(\mathrm{T}_{n}\right)\right)=\left\lceil\frac{n}{2}\right\rceil$. Jadi, dapat disimpulkan bilangan dominasi invers pada graf ular segitiga ganda yaitu $\gamma^{-1}\left(\mathrm{D}\left(\mathrm{T}_{n}\right)\right)=\left\lceil\frac{n}{2}\right\rceil$.

Contoh 12 Diberikan graf ular segitiga ganda $D\left(T_{3}\right)$.

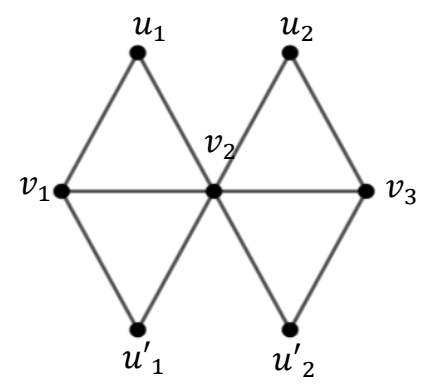

\section{Gambar 7 Graf $D\left(T_{3}\right)$}

Pada Gambar 7 dapat dilihat himpunan dominasi pada graf $D\left(T_{3}\right)$ dengan kardinalitas minimum yaitu $D=\left\{v_{2}\right\}$ dengan simpul $v_{2}$ mendominasi simpul $\left\{v_{1}, u_{1}, u_{1}^{\prime}, u_{2}, u_{2}^{\prime}, v_{3}\right\}$. Himpunan $V-D$ adalah $\left\{v_{1}, u_{1}, u_{1}^{\prime}, u_{2}, u_{2}^{\prime}, v_{3}\right\}$ saling bertetangga dengan simpul dari $D$. Simpul $v_{1}$ mendominasi simpul $\left\{u_{1}, u_{1}^{\prime}, v_{2}\right\}$ dan simpul $v_{3}$ mendominasi simpul $\left\{v_{2}, u_{2}, u_{2}^{\prime}\right\}$. Akibatnya himpunan dominasi invers dengan kardinalitas minimum adalah $D^{\prime}=\left\{v_{1}, v_{3}\right\}$ dan diperoleh bilangan dominasi invers $\gamma^{-1} D\left(T_{3}\right)$ $=2$.

\section{Bilangan Dominasi Invers pada $S\left(Q_{n}\right)$}

Berikut ini diberikan proposisi untuk graf ular segiempat $S\left(Q_{n}\right)$ :

Proposisi 13 Diberikan graf ular segiempat $S\left(Q_{n}\right)$ dengan $n \geq 3$, maka bilangan dominasi invers $\gamma^{-1}\left(\mathrm{~S}\left(\mathrm{Q}_{n}\right)\right)=n$.

Bukti : Diberikan graf ular segiempat dengan $n \geq 3$ dan himpunan simpul $V\left(\mathrm{~S}\left(\mathrm{Q}_{n}\right)\right)=\left\{v_{1}, v_{2}, \ldots\right.$, $\left.v_{n}, u_{1}, u_{2}, \ldots, u_{2 n-2}\right\}$. Ambil $v_{i} \in V\left(\mathrm{~S}\left(\mathrm{Q}_{n}\right)\right)$ dengan $i \in\{1,2,3,4, \ldots, n\}$ sehingga

1. $v_{1}$ mendominasi simpul $\left\{u_{1}, v_{2}\right\}$

2. $v_{2}$ mendominasi simpul $\left\{u_{2}, u_{3}, v_{1}, v_{3}\right\}$

3. $v_{3}$ mendominasi simpul $\left\{u_{4}, u_{5}, v_{2}, v_{4}\right\}$

4. $v_{4}$ mendominasi simpul $\left\{u_{6}, u_{7}, v_{3}, v_{5}\right\}$

Dengan cara serupa untuk $i \in\{1\}, v_{i}$ mendominasi himpunan $\left\{u_{i}, v_{i+1}\right\}$ dan untuk $i \in\{2,3,4, \ldots, n\}$, $v_{i}$ mendominasi himpunan $\left\{u_{2 i-2}, u_{2 i-1}, v_{i-1}, v_{i+1}\right\}$. Akibatnya, setiap simpul bisa mendominasi maksimal 4 simpul disekitarnya untuk $i$ lainnya hanya bisa mendominasi maksimal 2 simpul disekitarnya, sehingga diperoleh himpunan dominasi untuk graf ular segiempat salah satunya yaitu $D=\left\{v_{1}, v_{2}, v_{3}, v_{4}, \ldots, v_{n}\right\}$. Selanjutnya ambil $u_{j} \in V-D$ dengan $j \in\{1,2,4,6, \ldots, 2 n-2\}$ sehingga

1. $u_{1}$ mendominasi simpul $\left\{v_{1}, u_{2}\right\}$

2. $u_{2}$ mendominasi simpul $\left\{v_{2}, u_{1}\right\}$

3. $u_{4}$ mendominasi simpul $\left\{v_{3}, u_{3}\right\}$

4. $u_{6}$ mendominasi simpul $\left\{v_{4}, u_{5}\right\}$

Dengan cara serupa untuk $i \in\{1\}, v_{i}$ mendominasi himpunan $\left\{v_{i}, u_{i+1}\right\}$ dan untuk $i \in\{2,4,6, \ldots, n\}$, $v_{i}$ mendominasi himpunan $\left\{v_{i-\left(\frac{i}{2}-1\right)}, u_{i-1}\right\}$. Oleh karena itu, dapat dipilih salah satu himpunan dominasi invers pada graf $S\left(Q_{n}\right)$ yaitu $D^{\prime}=\left\{u_{1}, u_{2}, u_{4}, u_{6}, \ldots, u_{2(n)}\right\}$. Bilangan dominasi invers dihitung dari banyaknya anggota pada himpunan $D^{\prime}$. Berdasarkan indeks pada himpunan $D^{\prime}$, simpul pertamanya 
dimulai dari $u_{2}$ dan beda 2 untuk simpul selanjutnya. Pada himpunan $D^{\prime}$ indeks terbesarnya adalah 2(n). Indeks pada himpunan $D^{\prime}$ dapat disusun menjadi suatu barisan aritmatika sebagai berikut :

$$
D^{\prime}=\{2,4,6, \ldots, 2(n)\}
$$

Banyaknya anggota himpunan tersebut dapat diperoleh dengan menggunakan rumus barisan aritmatika dengan beda 2 dan suku pertama 2 sehingga pada himpunan $D^{\prime}$ suku ke $n$ yaitu $n$. Akibatnya, banyak anggota himpunan dominasi invers yang paling sedikit dari graf ular segiempat haruslah $\gamma^{-1}\left(\mathrm{~S}\left(\mathrm{Q}_{n}\right)\right) \leq n$. Selanjutnya akan ditunjukkan bilangan dominasi invers pada graf ular segiempat adalah $\gamma^{-1}\left(\mathrm{~S}\left(\mathrm{Q}_{n}\right)\right)=n$. Berdasarkan Tabel 1 bahwa $\gamma\left(\mathrm{S}\left(\mathrm{Q}_{n}\right)\right)=n$, sehingga berdasarkan Definisi 3 diperoleh bahwa $\gamma^{-1}\left(\mathrm{~S}\left(\mathrm{Q}_{n}\right)\right) \geq n$ Jadi, dapat disimpulkan bahwa bilangan dominasi invers pada graf ular segiempat yaitu $\gamma^{-1}\left(\mathrm{~S}\left(\mathrm{Q}_{n}\right)\right)=n$.

Contoh 14 Diberikan graf ular segiempat $S\left(Q_{3}\right)$.

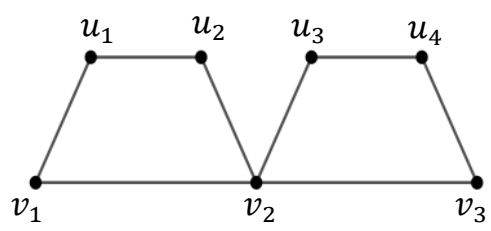

Gambar 8 Graf $S\left(Q_{3}\right)$

Pada Gambar 8 dapat dilihat himpunan dominasi pada graf $S\left(Q_{3}\right)$ dengan kardinalitas minimum yaitu $D=\left\{v_{1}, v_{2}, v_{3}\right\}$ dengan simpul $v_{1}$ mendominasi simpul $\left\{u_{1}, v_{2}\right\}$. Simpul $v_{2}$ mendominasi simpul $\left\{v_{1}, u_{2}, v_{3}, u_{3}\right\}$. Simpul $v_{3}$ mendominasi simpul $\left\{v_{2}, u_{4}\right\}$. Himpunan $V-D$ adalah $\left\{u_{1}, u_{2}, u_{3}, u_{4}\right\}$ saling bertetangga dengan simpul dari $D$. Simpul $u_{1}$ mendominasi simpul $\left\{v_{1}, u_{2}\right\}$. Simpul $u_{2}$ mendominasi simpul $\left\{u_{1}, v_{2}\right\}$ dan simpul $u_{4}$ mendominasi simpul $\left\{v_{3}, u_{3}\right\}$. Akibatnya himpunan dominasi invers dengan kardinalitas minimum adalah $D^{\prime}=\left\{u_{1}, u_{2}, u_{4}\right\}$ dan diperoleh bilangan dominasi invers $\gamma^{-1} S\left(Q_{3}\right)=3$.

\section{Bilangan Dominasi Invers pada $D\left(Q_{n}\right)$}

Berikut ini diberikan proposisi untuk graf ular segiempat ganda $D\left(Q_{n}\right)$ :

Proposisi 15 Diberikan graf ular segiempat ganda $D\left(Q_{n}\right)$ dengan $n \geq 3$, maka bilangan dominasi invers $\gamma^{-1}\left(\mathrm{D}\left(\mathrm{Q}_{n}\right)\right)=2 n-2$.

Bukti : Diberikan graf ular segiempat ganda dengan $n \geq 3$ dan himpunan simpul $V\left(D\left(Q_{n}\right)\right)=$ $\left\{v_{1}, v_{2}, \ldots, v_{n}, u_{1}, u_{2}, \ldots, u_{2 n-2}, u_{1}^{\prime}, u_{2}^{\prime}, \ldots, u_{2 n-2}^{\prime}\right\}$. Ambil $v_{i} \in V\left(D\left(Q_{n}\right)\right)$ dengan $i \in\{1,2,3,4, \ldots, n\}$ sehingga

1. $v_{1}$ mendominasi simpul $\left\{u_{1}, u_{1}^{\prime}, v_{2}\right\}$

2. $v_{2}$ mendominasi simpul $\left\{u_{2}, u_{3}, u_{2}^{\prime}, u_{3}^{\prime}, v_{1}, v_{3}\right\}$

3. $v_{3}$ mendominasi simpul $\left\{u_{4}, u_{5}, u_{4}^{\prime}, u_{5}^{\prime}, v_{2}, v_{4}\right\}$

4. $v_{4}$ mendominasi simpul $\left\{u_{6}, u_{7}, u_{6}^{\prime}, u^{\prime}{ }_{7}, v_{3}, v_{5}\right\}$

Dengan cara serupa untuk $i \in\{1\}, v_{i}$ mendominasi himpunan $\left\{u_{i}, u_{i}^{\prime}, v_{i+1}\right\}$ dan untuk $i \in$ $\{2,3,4, \ldots, n\}, v_{i}$ mendominasi himpunan $\left\{u_{2 i-2}, u_{2 i-1}, u_{2 i-2}^{\prime}, u_{2 i-1}^{\prime}, v_{i-1}, v_{i+1}\right\}$. Akibatnya, setiap simpul bisa mendominasi maksimal 6 simpul disekitarnya untuk $i$ lainnya hanya bisa mendominasi maksimal 4 simpul disekitarnya, sehingga diperoleh bilangan dominasi invers untuk graf ular segiempat ganda salah satunya yaitu $D=\left\{v_{1}, v_{2}, v_{3}, v_{4}, \ldots, v_{n}\right\}$. Selanjutnya ambil $u_{j}$ dan $u_{j}^{\prime} \in V-$ Duntuk $u_{j}$ dengan $j \in\{1,3,5,7 \ldots, 2 n-2\}$ dan untuk $u_{j}^{\prime}$ dengan $j \in\{2,4,6,8 \ldots, 2 n-2\}$ sehingga

1. $u_{1}$ mendominasi simpul $\left\{v_{1}, u_{2}\right\}$

2. $u_{3}$ mendominasi simpul $\left\{v_{2}, u_{4}\right\}$

3. $u_{5}$ mendominasi simpul $\left\{v_{3}, u_{6}\right\}$ 
4. $u_{7}$ mendominasi simpul $\left\{v_{4}, u_{8}\right\}$

Dengan cara serupa untuk $i \in\{1\}, v_{i}$ mendominasi himpunan $\left\{v_{i}, u_{i+1}\right\}$ dan untuk $i \in\{3,5,7, \ldots, n\}$, $v_{i}$ mendominasi himpunan $\left\{v_{i-\left(\frac{i}{2}-1\right)}, u_{i+1}\right\}$.

1. $u_{2}^{\prime}$ mendominasi simpul $\left\{v_{2}, u_{1}^{\prime}\right\}$

2. $u_{4}^{\prime}$ mendominasi simpul $\left\{v_{3}, u_{3}^{\prime}\right\}$

3. $u_{6}^{\prime}$ mendominasi simpul $\left\{v_{4}, u_{5}^{\prime}\right\}$

4. $u_{8}^{\prime}$ mendominasi simpul $\left\{v_{5}, u_{7}^{\prime}\right\}$

Dengan cara serupa untuk $i \in\{2,4,6, \ldots, n\}, v_{i}$ mendominasi himpunan $\left\{v_{i-\left(\frac{i}{2}-1\right)}, u_{i-1}\right\}$. Oleh karena itu, dapat dipilih salah satu himpunan dominasi invers pada graf $D\left(Q_{n}\right)$ yaitu $D^{\prime}=\left\{u_{1}, u_{2}^{\prime}, u_{3}, u_{4}^{\prime}, \ldots, u_{2(2 n-2)-1)}, u_{2(2 n-2)}^{\prime}\right\}$. Bilangan dominasi invers dihitung dari banyaknya anggota pada himpunan $D^{\prime}$. Berdasarkan indeks pada himpunan $D^{\prime}$, untuk $u_{i}$ simpul pertamanya dimulai dari $u_{1}$ dan beda 2 untuk simpul selanjutnya dan untuk $u_{i}^{\prime}$ simpul pertamanya dimulai dari $u_{2}^{\prime}$ dan beda 2 untuk simpul selanjutnya. Pada himpunan $D^{\prime}$ indeks terbesarnya adalah $\left.2(2 n-2)-1\right)$ untuk $u_{i}$ dan $2(2 n-2)$ untuk $u_{i}$. Indeks pada himpunan $D^{\prime}$ dapat disusun menjadi suatu barisan aritmatika sebagai berikut :

1. $D^{\prime}=\{1,3,5, \ldots, 2(2 n-2)-1\}$ untuk $u_{i}$

2. $D^{\prime}=\{2,4,6, \ldots, 2(2 n-2)\}$ untuk $u_{i}^{\prime}$

Banyaknya anggota himpunan tersebut dapat diperoleh dengan menggunakan rumus barisan aritmatika dengan beda 2 dan suku pertama 1 untuk $u_{i}$ dan suku pertama 2 untuk $u_{i}^{\prime}$ sehingga pada himpunan $D^{\prime}$ suku ke $n$ yaitu $(2 n-2)$. Akibatnya, banyaknya anggota himpunan dominasi invers yang paling sedikit dari graf ular segiempat ganda yaitu, $\gamma^{-1}\left(D\left(Q_{n}\right)\right) \leq(2 n-2)$. Selanjutnya akan ditunjukkan bilangan dominasi invers pada graf ular segiempat ganda adalah $\gamma^{-1}\left(D\left(Q_{n}\right)\right)=(2 n-2)$. Misal $\gamma^{-1}\left(D\left(Q T_{n}\right)\right)=(2 n-2)-1$, maka terdapat $(2 n-2)-1$ simpul yang merupakan himpunan dominasi invers pada graf ular segiempat ganda dengan kardinalitas minimum. Jika terdapat ( $2 n-$ 2) - 1 simpul pada himpunan dominasi invers yang dipilih sembarang, maka mengakibatkan setidaknya 2 simpul pada graf $D\left(Q_{n}\right)$ yang tidak terdominasi. Hal tersebut kontradiksi dengan definisi bilangan dominasi invers, dengan kata lain, haruslah $\gamma^{-1}\left(D\left(Q_{n}\right)\right)=(2 n-2)$. Jadi, dapat disimpulkan bilangan dominasi invers pada graf ular segiempat ganda yaitu $\gamma^{-1}\left(D\left(Q_{n}\right)\right)=(2 n-2)$.

Contoh 16 Diberikan graf ular segiempat ganda dengan 11 simpul dan 14 sisi.

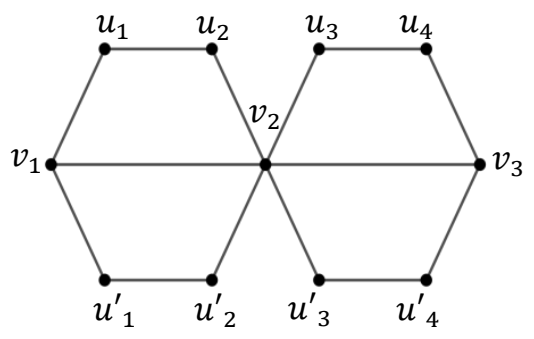

Gambar 9 Graf $D\left(Q_{3}\right)$

Pada Gambar 9 dapat dilihat himpunan dominasi pada graf $\mathrm{D}\left(\mathrm{Q}_{3}\right)$ dengan kardinalitas minimum yaitu $D=\left\{v_{1}, v_{2}, v_{3}\right\}$ dengan simpul $v_{1}$ mendominasi simpul $\left\{u_{1}, u_{1}^{\prime}, v_{2}\right\}$. Simpul $v_{2}$ mendominasi simpul $\left\{v_{1}, u_{2}, u_{2}^{\prime}, v_{3}, u_{3}, u^{\prime}{ }_{3}\right\}$. Simpul $v_{3}$ mendominasi simpul $\left\{v_{2}, u_{4}, u_{4}^{\prime}\right\}$. Himpunan $V-D$ adalah $\left\{u_{1}, u_{1}^{\prime}, u_{2}, u_{2}^{\prime}, u_{3}, u_{3}^{\prime}, u_{4}, u_{4}^{\prime}\right\}$ saling bertetangga dengan simpul dari $D$. Simpul $u_{1}$ mendominasi simpul $\left\{v_{1}, u_{2}\right\}$. Simpul $u_{3}$ mendominasi simpul $\left\{v_{2}, u_{4}\right\}$. Simpul $u_{2}^{\prime}$ mendominasi simpul $\left\{u_{1}^{\prime}, v_{2}\right\}$ 
dan simpul $u_{4}^{\prime}$ mendominasi simpul $\left\{u_{3}^{\prime}, v_{3}\right\}$. Akibatnya himpunan dominasi invers dengan kardinalitas minimum adalah $D^{\prime}=\left\{u_{1}, u_{2}^{\prime}, u_{3}, u_{4}^{\prime}\right\}$ dan diperoleh bilangan dominasi invers yaitu $\gamma^{-1} D\left(Q_{3}\right)=4$.

\section{KESIMPULAN}

Bilangan dominasi invers merupakan kardinalitas minimum dari himpunan dominasi invers. Bilangan dominasi invers pada graf lintasan, cycle, ular segitiga, ular segitiga ganda, ular segiempat dan ular segiempat ganda diperoleh dengan cara mencari himpunan dominasi dengan kardinalitas minimum pada setiap graf tersebut, kemudian mencari himpunan dominasi inversnya, selanjutntya mencari satu persatu bilangan dominasi inversnya. Pada tahap akhir akan diperoleh pola bilangan dominasi invers pada masing-masing graf. Pada penelitian ini diperoleh beberapa bilangan dominasi invers dari beberapa graf yaitu, $\gamma^{-1}\left(P_{n}\right)=\left\lceil\frac{n}{3}\right\rceil+1$ untuk $n=3 k$ dengan $k \in \square, \gamma^{-1}\left(P_{n}\right)=\left\lceil\frac{n}{3}\right\rceil$ untuk $n$ lainnya, $\gamma^{-1}\left(C_{n}\right)=\left\lceil\frac{n}{3}\right\rceil, \gamma^{-1}\left(S\left(T_{n}\right)\right)=\left\lceil\frac{n}{2}\right\rceil, \gamma^{-1}\left(D\left(T_{n}\right)\right)=\left\lceil\frac{n}{2}\right\rceil, \gamma^{-1}\left(S\left(Q_{n}\right)\right)=n \operatorname{dan}^{-1}\left(D\left(Q_{n}\right)\right)=2 n-2$.

\section{DAFTAR PUSTAKA}

[1] Munir, R. Matematika Diskrit Ed ke-3. Bandung: Teknik Informatika; 2010.

[2] Afandi, Y. Pewarnaan Minimal Graf Piramida dan Berlian. Malang: UIN Maulana Malik Ibrahim; 2009.

[3] Santoso, B.; Djuwandi dan Soelistyo, R. H. Bilangan Dominasi dan Bilangan Kebebasan Graf Bipartit Kubik. Jurnal Matematika. 2012; Vol. 15, No. 1.

[4] Adawiyah, R. Penentuan Bilangan Dominasi Sisi pada Graf Hasil Operasi Produk Tensor. Surabaya: Institut Teknologi 10 Nopember; 2016.

[5] Kulli,V. R. dan Sigarkanti, S. C. Inverse Domination in Graphs. Nat. Acad. Sci. Letters. 1991; Vol. 14, No. 12, 473-475.

[6] Chelvam, T. T.; Asir, T. dan Prema G. G. S. Inverse Domination in Graphs. Lambert Academic Publishing; 2013.

[7] Vaidya, S. K. dan Pandit, R. M. Edge Domination in Various Snake Graphs. International Journal of Mathematics and Soft Computing. 2017; Vol. 7, No. 1, 43-50.

ANGGUN FITRIA FEBRIANTI

MARIATUL KIFTIAH

FRANSISKUS FRAN
: Jurusan Matematika FMIPA UNTAN, Pontianak anggunfitria02@gmail.com

: Jurusan Matematika FMIPA UNTAN, Pontianak kiftiahmariatul@math.untan.ac.id

: Jurusan Matematika FMIPA UNTAN, Pontianak fransiskusfran@math.untan.ac.id 